Article

\title{
Interatomic diffusion in Pd-Pt core-shell nanoparticles
}

\author{
Yanfeng Zhang a,b,c,, , Shangqian Zhu ${ }^{b, \dagger}$, Lili Zhang b,d, Dong Su e, Minhua Shao ${ }^{b, *}$ \\ a Jiangsu Aoxin NEV Co., Ltd, Yancheng, Jiangsu, China \\ b Department of Chemical and Biological Engineering, Hong Kong University of Science and Technology, Clear Water Bay, Kowloon, Hong Kong, China \\ c Shanghai AI NEV Innovative Platform Co., Ltd, Shanghai, China \\ d Jiangsu Key Laboratory for Chemistry of Low-Dimension Materials, Huaiyin Normal University, Huaian 223300, Jiangsu, China \\ e Center for Functional Nanomaterials, Brookhaven National Laboratory, Upton, NY 11973, USA
}

\section{A R T I C L E I N F O}

\section{Article history:}

Received 22 August 2019

Accepted 11 October 2019

Published 5 May 2020

\section{Keywords:}

Monolayer

Proton exchange membrane fuel cell

Stability

Interatomic-diffusion

Electrocatalysis

\begin{abstract}
A B S T R A C T
Pt monolayer-based core-shell catalysts have garnered significant interest for the application of low temperature fuel cell technology as their use may enable a decreased loading of Pt while still providing sufficient current density to meet volumetric requirements. One promising candidate in this class of materials is a Pd@Pt core-shell catalyst, which shows enhanced activity toward oxygen reduction reaction (ORR). One concern with the use of Pd@Pt, however, is the durability of the core-shell structure as Pd atoms are thermodynamically favored to migrate to the surface. The pathway of the migration has not been systematically studied. The current study explores the stability of this structure to thermal annealing and probes the effect of this heat treatment on the catalyst surface structure and its oxygen reduction activity. It was found that surface alloying between $\mathrm{Pd}$ and Pt occurs at temperatures as low as $200{ }^{\circ} \mathrm{C}$, and significantly alters the structure and ORR catalytic activity in the range of $200-300^{\circ} \mathrm{C}$. Our results shed lights on the thermal induced interatomic diffusion in all core-shell and thin film structures.
\end{abstract}

(C) 2020, Dalian Institute of Chemical Physics, Chinese Academy of Sciences. Published by Elsevier B.V. All rights reserved.

\section{Introduction}

Core-shell nanoparticles consisting of a Pd core and a Pt-based shell with one or a few atomic monolayer thickness have attracted great attention due to their unique properties [1-9]. Most importantly, this Pd@Pt core-shell nanostructure allows efficient utilization of the scarce and expensive Pt by improving its dispersion. Additionally, compressive strain in the Pt surface atoms is induced by the underlying Pd lattice that weakens the interaction of oxygen-containing species with the surface of Pd@Pt in comparison to that with Pt nanoparticles
$[1,10]$. The weakened oxygen binding energy can promote a more active electrocatalyst toward oxygen reduction reaction (ORR) due to the presence of fewer $\mathrm{OH}$ groups blocking the sites $[10,11]$. The combination of these factors promotes an improvement in Pt mass activity at $0.9 \mathrm{~V}$ by up to 5 times in comparison to the commercial Pt/C [12]. Because of these beneficial properties, Pd@Pt core-shell catalysts have garnered significant interest for the application in low temperature fuel cell technology as their use may enable a decreased loading of Pt while still providing sufficient current density to meet volumetric requirements. Despite these attractive properties, one

\footnotetext{
† Equal contribution.

* Corresponding author. Tel: +852-34692269; E-mail: kemshao@ust.hk

The authors acknowledge the support from Jiangsu High-level Innovation and Entrepreneurship Talent Plan in 2017, National Key R\&D Program of China (2017YFB0102900), and Research Grant Council (26206115 and 16304117) of the Hong Kong Special Administrative Region, and Guangdong Special Fund for Science and Technology Development (Hong Kong Technology Cooperation Funding Scheme (201604030012, 201704030065). DOI: S1872-2067(19)63451-0 | http://www.sciencedirect.com/science/journal/18722067 | Chin. J. Catal., Vol. 41, No. 5, May 2020
} 
concern about their use is the structural stability of the core-shell nanoparticle. Under certain conditions there is a thermodynamic driving force for Pd segregation to the surface and/or mixing of the Pt and Pd near the surface. Due to the relatively low activity and stability of Pd and Pd-Pt alloys [13], this occurrence can significantly decrease the activity and long-term durability of the core-shell catalyst.

The fuel cell performance of Pd@Pt catalysts, however, is still unsatisfactory in consideration of its huge improvement over Pt/C by rotating disk electrode testing in the liquid cell. We even found that the fuel cell performance of Pd@Pt catalysts was even lower than that of $\mathrm{Pt} / \mathrm{C}$. We suspect that catalysts might undergo a structure change from core-shell to alloy (at least in the surface and subsurface region) during the ink preparation step. Some dispersion techniques can generate a significant amount of thermal energy causing an increase of the local temperature. The thermal energy/local temperature is high enough to overcome the kinetic barrier of inter-diffusion between Pd and Pt atoms. The migration of the Pd atoms in the core to the surface has not been studied systematically. There is a lack of understanding of the pathways of atomic diffusion in the core-shell structure, the initial and propagation of atomic diffusion as a function of temperature at the atomic scale. More importantly, the threshold temperature at which the structure evolution starts to occur is unknown. In addition, the relationship between the activity and the structure has not been explored. In this work, the thermally induced evolution of Pd@Pt core-shell structures and its impact on the ORR activity are systematically studied by using in situ X-ray diffraction (XRD) [14], scanning transmission electron microscopy coupled with electron energy loss spectroscopy (STEM-EELS), and electrochemical techniques. It is confirmed that the obvious surface alloying of Pt and Pd occurs at temperatures as low as $200{ }^{\circ} \mathrm{C}$, which leads to a loss of activity toward ORR.

\section{Experimental}

\subsection{Synthesis of core-shell material}

A custom reactor was built to synthesize gram-scale batches of core-shell catalysts using commercial Pd nanoparticles supported on Ketjen Black (Pd/C) as the core materials (TKK, 35 $w \mathrm{t} \%$ ). The reactor comprised a graphite sheet as the working electrode, carbon cloth as the counter electrode, and an $\mathrm{Ag} / \mathrm{AgCl}$ leak-free reference electrode (BASi). The $\mathrm{Pd} / \mathrm{C}$ nanoparticles were dispersed in a $50 \mathrm{mM} \mathrm{H}_{2} \mathrm{SO}_{4}$ solution, and then added to the reactor. Pretreatment of the $\mathrm{Pd} / \mathrm{C}$ was conducted as needed to wet the powder. After pretreatment, a deaerated aqueous $\mathrm{CuSO}_{4}$ solution in $50 \mathrm{mM} \mathrm{H}_{2} \mathrm{SO}_{4}$ was added to the reactor to obtain a $\mathrm{Cu}^{2+}$ concentration of $50 \mathrm{mM}$. After addition of the $\mathrm{CuSO}_{4}$, the potential was held at approximately $0.37 \mathrm{~V}$ vs. $\mathrm{Ag} / \mathrm{AgCl}$ to deposit an atomically thin layer of $\mathrm{Cu}$ on the $\mathrm{Pd}$ nanoparticles. Immediately upon completion of the $\mathrm{Cu}$ UPD (under potential deposition), a deaerated aqueous solution of $\mathrm{K}_{2} \mathrm{PtCl}_{4}$ was added dropwise to the reactor to perform galvanic replacement of the $\mathrm{Cu}$ by the Pt. In addition to the Pt precursor, citric acid was also included in the Pt precursor solution to minimize the formation of Pt clusters. After the reaction was complete, typically in 30 minutes, catalysts were filtered and rinsed with ultrapure water (Milli-Q UV-plus water). The resulting catalyst powder, denoted as Pd@Pt/C, was dried in a vacuum at $60{ }^{\circ} \mathrm{C}$. Only a trace amount of $\mathrm{Cu}$ (less than $0.4 \%$ ) remained in the final product based on inductively coupled plasma-mass spectrometry (ICP-MS) measurements.

The resulting Pd@Pt/C material was subsequently heat treated in a quartz tube furnace under an inert Ar atmosphere with a flow rate of approximately $100 \mathrm{~mL} \mathrm{~min}^{-1}$. The atmosphere was first purged for $1 \mathrm{~h}$ to remove oxygen prior to elevation of the temperature. The temperature program consisted of a $1 \mathrm{~h}$ ramp to and then a $30 \mathrm{~min}$ hold at the desired temperature, followed by turning off the heating elements and allowing the material to cool under the flow of Ar. It is assumed that the metal loadings of the annealed materials are the same as the untreated one, a good assumption for the relatively low temperatures used in this study at which carbon combustion is not expected.

\subsection{Electrochemical measurements}

The ability of these materials to catalyze the electrochemical reduction of oxygen was determined via the rotating disk electrode (RDE) method. Approximately $15 \mathrm{mg}$ of the Pd@Pt/C material was dispersed in a solvent consisting of $7.5 \mathrm{~mL}$ of MilliQ UV-plus water, $7.5 \mathrm{~mL}$ of isopropanol and $60 \mu \mathrm{L}$ of $5 \mathrm{wt} . \%$, 1100 EW Nafion (Ion Power) via 30 minutes of sonication. Ten $\mu \mathrm{L}$ of the ink was pipetted onto a polished glassy carbon substrate (RDE, $5 \mathrm{~mm}$ diameter, Pine Instruments) and allowed to dry. The Pt loading on the electrode was about $1 \mu \mathrm{g}$. The resulting electrode was placed in a three electrode electrochemical cell containing $0.1 \mathrm{M}$ aqueous perchloric acid $\left(\mathrm{HClO}_{4}\right.$, GFS Chemicals) solution. The working electrode in the setup was the RDE, the counter electrode was a Pt mesh pressed onto a Pt wire, and a reversible hydrogen electrode (RHE) was used to measure the potential. All the potentials were referred to the RHE scale if not otherwise mentioned. Prior to evaluation of the material, ten cyclic voltammetry (CV) cycles between 0.05 and $1.2 \mathrm{~V}$ at a scan rate of $100 \mathrm{mV} \mathrm{s}^{-1}$ were performed in $\mathrm{N}_{2}$-saturated $\mathrm{HClO}_{4}$ to clean the surface of the catalyst. After cleaning, the electrochemically active surface area (ECA) of the material was determined by performing $2 \mathrm{CV}$ cycles from 0.05 to $1.2 \mathrm{~V}$ at $50 \mathrm{mV} \mathrm{s}^{-1}$. For this, the hydrogen adsorption peak was integrated to determine the charge, and this was divided by $210 \mu \mathrm{C} \mathrm{cm}^{-2}$, the charge density of an adsorbed monolayer of hydrogen atoms [15]. Finally, the electrode was evaluated for its oxygen reduction reaction (ORR) activity by potential cycling from 1.1 to $0.1 \mathrm{~V}$ at $10 \mathrm{mV} \mathrm{s}^{-1}$ while rotating the RDE at $1600 \mathrm{rpm}$ in $\mathrm{O}_{2}$-saturated $0.1 \mathrm{M} \mathrm{HClO}_{4}$. The kinetic current, $i_{\mathrm{k}}$, at $0.9 \mathrm{~V}$ was calculated from the Koutecky-Levich equation,

$$
1 / i=1 / i_{k}+1 / i_{L}
$$

where $i$ is the measured current and $i_{\mathrm{L}}$ is the diffusion limited current. It is noted that the current was measured during the anodic potential sweep. The specific activity (SA) and mass activity (MA) were then calculated by normalizing the kinetic current by surface area and Pt mass, respectively. 
CO stripping was performed to help elucidate the surface structural changes during thermal treatment. These experiments were performed with the RDE setup described above. After cleaning the surface of the catalyst via potential cycling, the potential was held at $100 \mathrm{mV}$ vs RHE in CO-saturated $0.1 \mathrm{M}$ $\mathrm{HClO}_{4}$. After holding the potential for $15 \mathrm{~min}$, the cell was then purged with $\mathrm{N}_{2}$ for 30 min while continuing to hold the potential at $100 \mathrm{mV}$. Finally, cyclic voltammetry was performed with a scan rate of $20 \mathrm{mV} \mathrm{s}^{-1}$ to electrochemically desorb the $\mathrm{CO}$ and to observe the hydrogen adsorption-desorption peaks on the catalyst surface.

\subsection{Materials characterizations}

In situ XRD experiments were performed at Beamline X18A at the National Synchrotron Light Source (NSLS) at Brookhaven National Laboratory (BNL) in Upton, NY. Briefly, helium (99.999\%, Praxair) and hydrogen (99.999\%, Praxair) were metered through a home-made sample cell by two mass flow controllers (Brooks 5850) at a flow rate of $\sim 20 \mathrm{~mL} \mathrm{~min}^{-1}$. The atmosphere was first purged with He to prevent burning the catalyst powders via the combustion of $\mathrm{H}_{2}$. The XRD spectra were recorded with a 2D detector (Perkin Elmer XRD $1621 \mathrm{~N}$ ES) at $20 \mathrm{keV}$ (calibrated by the Mo $K$ absorption $(\lambda=0.7107 \AA$ ) and subsequently processed by standard software. The dark current was collected over $40 \mathrm{~s}$ (10 exposures at $4 \mathrm{~s}$ per exposure) and the diffraction pattern was recorded over $400 \mathrm{~s}(100$ exposures at $4 \mathrm{~s}$ per exposure). After recording the XRD pattern under an inert atmosphere, the cell was purged with $\mathrm{H}_{2}$ for 10 min and the XRD spectra were then recorded under this atmosphere. Further purging with $\mathrm{H}_{2}$ did not affect the structure of the material. Finally, the cell was purged with He for 10 minutes and a post- $\mathrm{H}_{2}$ exposure XRD spectrum was recorded. The sample to detector distance was approximately $400 \mathrm{~mm}$ and was calibrated by the use of titanium dioxide (rutile) powder loaded into the sample holder of the cell in an identical fashion as done for catalyst characterization. Performing a calculation of error propagation suggests that an error in sample position of $+/-1 \mathrm{~mm}$ will result in an error in the lattice constant of $+/-0.001 \mathrm{~nm}$. Further, there is an internal calibration standard for each sample corresponding to amorphous carbon peak, which is present in all of the XRD spectra collected in this work, and which always lies at the same value of $2 \theta$. All data was processed by standard data processing software, and the data was transformed to enable direct comparison to data collected with $\mathrm{Cu} K_{\alpha}$ incident X-ray irradiation.

High angle annular dark-field scanning transmission electron microscopy (HAADF-STEM) images and electron energy loss spectroscopy (EELS) data were collected using a Hitachi aberration-corrected scanning transmission electron microscope (HD-2700C). An electron probe diameter of 1.3 Å with a convergence angle of $28 \mathrm{mrad}$ was used. At these experimental conditions, the contrast present in the HAADF images is directly related to the atomic number and thickness of the materials. The EELS line scans were collected with a pixel time of 0.02 and $1 \mathrm{~s}$, respectively, using a Gatan Enfina-ER detector.

\section{Results and discussion}

To experimentally probe the stability of the Pd@Pt core-shell structure to thermal energy, a combination of bulk analysis techniques were performed. In situ STEM-EELS provides evidence of an as synthesized core-shell structure and demonstrates mixing of Pd and Pt during annealing. Before treatment (Fig. 1(a)), two sharp Pt peaks at the each end of the EELS spatial scan demonstrated the existence of a thin Pt shell (1-2 atomic layers) on Pd. After thermal annealing in the TEM chamber for $30 \mathrm{~min}$ at $250{ }^{\circ} \mathrm{C}$, these features in the same particle disappeared as shown in Fig. 1(b). This result implies that the uniform Pt shell was damaged during heat treatment at 250 ${ }^{\circ} \mathrm{C}$ due to the mixing of Pd-Pt atoms on the surface.

In situ XRD in a $\mathrm{H}_{2}$ atmosphere enables real-time evaluation of Pd-Pt alloying upon exposure to elevated temperatures. This technique is rooted in the unique ability of Pd to absorb hydrogen to form Pd hydrides $\left(\mathrm{PdH}_{x}\right)$, which causes expansion in its lattice parameter from 3.89 to $\sim 4.05 \AA$ for $\mathrm{PdH}_{0.7}[16,17]$. This shift enables the deconvolution of the Pd spectrum from Pt, which has a lattice parameter of $3.92 \AA$, and cannot be resolved from $\mathrm{Pd}$ in standard XRD measurements (in a He atmosphere in this study). For a Pd@Pt core-shell structure, it is
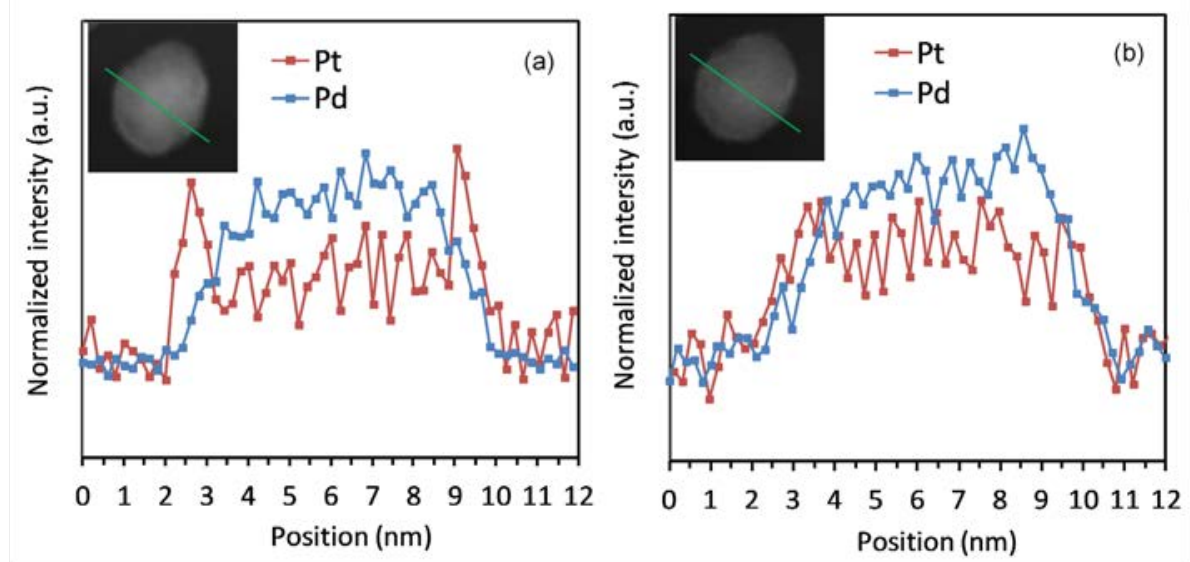

Fig. 1. STEM images of a Pd@Pt particle and corresponding EELS intensities for Pt and Pd of as synthesized Pd@Pt (a), and that is annealed at $250{ }^{\circ} \mathrm{C}$ for $30 \mathrm{~min}$ (b). 
observed that the Pt shell is thin enough and/or has a sufficient number of defects (pinholes) to allow hydrogen to penetrate to the underlying Pd core where it is absorbed to form the Pd hydrides (Fig. S1) [12]. In turn, the Pd XRD peak shifts to a lower angle while the Pt spectrum is not shifted since Pt does not absorb hydrogen (Table S1). While the Pt peak will not shift, it is noted that a Pt monolayer is not detectable in a diffraction measurement since there is not sufficient long range order to create the constructive interference needed to observe a peak. Thus, the appearance of a peak corresponding to Pt in this measurement indicates the formation of Pt clusters, perhaps in the form of islands that are several atoms thick. Another consideration in interpreting this data is that the formation of Pd-Pt bonds could limit the ability of hydrogen to be absorbed by the Pd lattice. This will become more pronounced if there is mixing of the Pt and Pd near the surface. Supporting this notion is the fact that the lattice of a $\mathrm{Pd}_{4} \mathrm{Pt}$ alloy only shifts from 3.902 to $3.925 \AA$ upon exposure to hydrogen, an expansion of only $0.6 \%$ (Table S1). Clearly, any mixing of Pt and Pd in the structure will cause a decrease in the hydrogen uptake and a concomitant shift of the XRD reflection toward higher $2 \theta$. That said, changes in the peak profile as a response to temperature can unambiguously be attributed to mixing of the Pd and $\mathrm{Pt}$, or perhaps clustering of the Pt. Loss of the peak corresponding to $\mathrm{PdH}_{0.7}$, however, is indicative of $\mathrm{Pd}-\mathrm{Pt}$ alloying.

Fig. 2 illustrates the results of XRD measured in a $\mathrm{H}_{2}$ atmosphere for Pd@Pt/C that was annealed up to $300{ }^{\circ} \mathrm{C}$ in $\mathrm{Ar}$. The un-annealed Pd@Pt/C exhibited a peak with a maximum at $38.9^{\circ}$ assigned to the (111) plane and a slight tail toward high $2 \theta$. The peak location is in good agreement with that of $\mathrm{PdH}_{0.7}$, which is centered at $38.5^{\circ}$. This suggests that hydrogen is able to permeate through the Pt shell, and that the amount of hydrogen absorbed by the Pd is not significantly affected by the presence of a Pt shell. The presence of the tail is indicative of an atomic thin Pt shell as supported by the STEM-EELS result. As the Pd@Pt/C was annealed, its peak shifted toward higher $2 \theta$ starting at $200{ }^{\circ} \mathrm{C}$ with a shoulder remaining at $38.9^{\circ}$. This suggests that there remains a core of Pd in the center of the nanoparticle, but that the Pt and Pd mix and/or alloy near the surface. With increasing the annealing temperature, the peak further shifted to higher degrees. At $300{ }^{\circ} \mathrm{C}$, the peak increased to $39.3^{\circ}$.

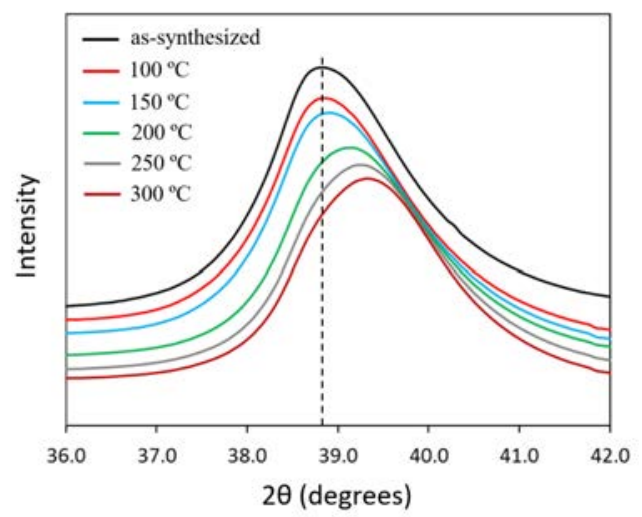

Fig. 2. In situ XRD spectra measured in a $\mathrm{H}_{2}$ atmosphere for Pd@Pt/C that was annealed from room temperature up to $300^{\circ} \mathrm{C}$ in $\mathrm{Ar}$.
Further supporting the hypothesis that the Pt and Pd are alloying near the particle surface is the CO stripping data exhibited in Fig. 3. As CO adsorption is not dissociative on these surfaces, the potential at which CO desorbs from the surface of these materials can be used to estimate the surface electronic properties of the catalyst. It is noted that this is a simplistic view of CO stripping since the actual mechanism of desorption involves the interaction of adsorbed hydroxyl species serving to react with $\mathrm{CO}$ to remove it from the surface. The CO stripping peak shifted negatively from 0.934 to $0.884 \mathrm{~V}$ when a Pt shell was deposited on the Pd/C core. Upon annealing the Pd@Pt/C, the potential of the $\mathrm{CO}$ stripping peak increased to $0.904 \mathrm{~V}$ for the material annealed at $200{ }^{\circ} \mathrm{C}$ and to $0.912 \mathrm{~V}$ for that annealed at $300{ }^{\circ} \mathrm{C}$. This is interpreted as being due to alloying of $\mathrm{Pt}$ and $\mathrm{Pd}$, with segregation of Pd to the surface being a strong possibility.

The surface alloying between $\mathrm{Pd}$ and Pt atoms may have a profound effect on the catalytic activity of Pd@Pt/C toward ORR. As shown in Fig. 4. the Pt mass activity at $0.9 \mathrm{~V}$ of the $\mathrm{Pd} @ \mathrm{Pt} / \mathrm{C}$ catalysts decreased by $37 \%$ when annealed to $200{ }^{\circ} \mathrm{C}$, and decreased by $56 \%$ after annealing at $300{ }^{\circ} \mathrm{C}$. The decrease of the activity is due to the fact that the surface Pd-Pt alloys are less active than the core-shell catalysts, which better utilize the available Pt atoms. Besides, previous experimental and theoretical studies indicated that the $\mathrm{Pt}-\mathrm{O}$ binding strength should be slightly weakened to balance the $0-0$ bond's rupture and O/OH intermediates removal to improve the ORR activity [18]. This can be achieved by adopting the strain and ligand effects to slightly lower the d-band center position of $\mathrm{Pt}$, for instance, the Pt/Pd surface [19]. The interatomic diffusion in Pd-Pt core-shell nanoparticles, however, would expose less-active sites that have a higher d-band center position than Pt/Pd (e.g. Pd, Pd-Pt alloy, Pt cluster and Pd/Pt) [19,20], and lower the catalysts activity. The thermal induced damage in the core-shell structure and accordingly lower activity can also explain the poor performance of Pd@Pt/C in fuel cell when the catalyst ink was prepared by dispersion techniques that can generate a significant amount of thermal energy.

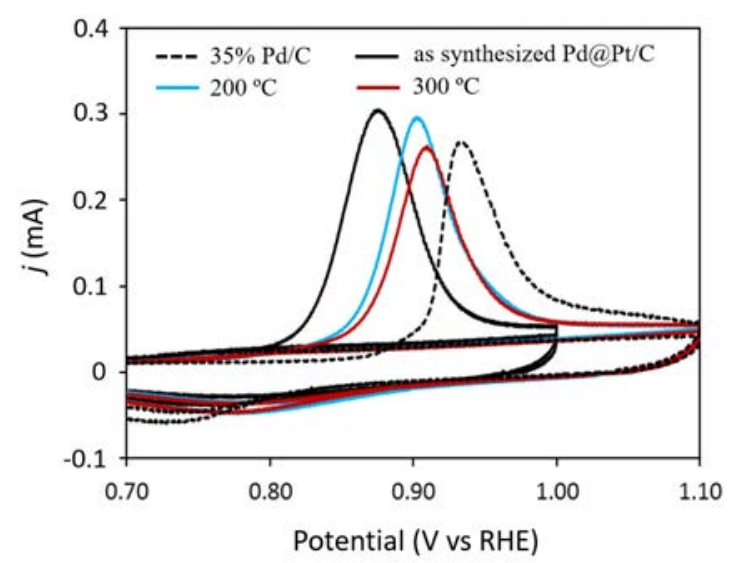

Fig. 3. CO stripping voltammetry on $\mathrm{Pd} / \mathrm{C}$ (black dashed line), as-synthesized (solid black line), annealed at $200{ }^{\circ} \mathrm{C}$ (solid blue line) and $300{ }^{\circ} \mathrm{C}$ (solid red line) Pd@Pt/C measured in $0.1 \mathrm{M} \mathrm{HClO}_{4}$ solution with a scanning rate of $20 \mathrm{mV} \mathrm{s}^{-1}$. 

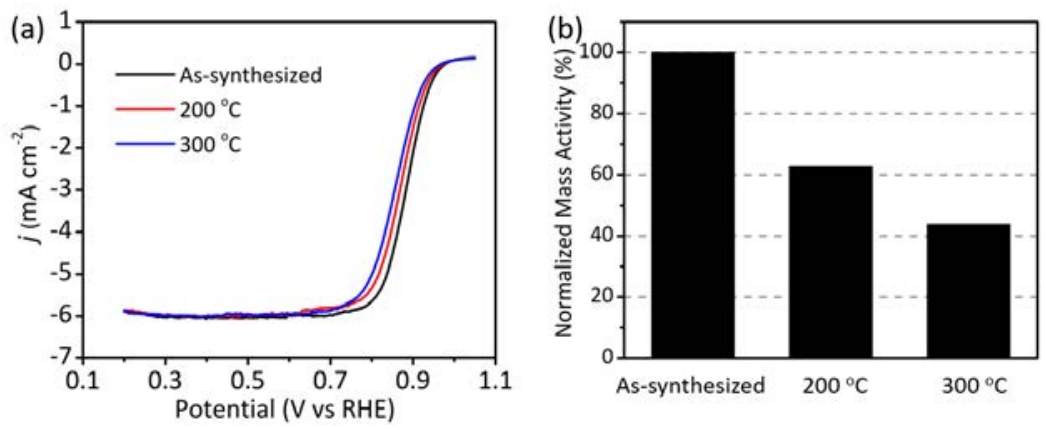

Fig. 4. Comparison of ORR polarization curve (a) and Pt mass activity (b) of as-synthesized and annealed Pd@Pt/C. The activity data was derived at $0.9 \mathrm{~V}$ and normalized to the value of the as-synthesized sample.

\section{Conclusions}

In summary, detailed physical characterizations and electrochemical measurements clearly demonstrated that the core-shell structure of Pd@Pt is not stable to thermal annealing. The mixing of Pd and Pt atoms occurs at temperatures as low as $200^{\circ} \mathrm{C}$, and significantly alters the structure and catalytic activity in the range of $200-300^{\circ} \mathrm{C}$. This could be problematic during the ink preparation process involving dispersion techniques generating a significant amount of heat, and membrane electrode assembly (MEA) fabrication requiring hot press. To realize the full potential of the core-shell structure to reduce the cost of fuel cell electrocatalysts, more work needs to be performed to study these issues before this class of materials will be successfully applied in PEM fuel cells. Our results also shed lights on the thermal induced interatomic diffusion issue in all core-shell and thin film structures.

\section{Acknowledgments}

The authors acknowledge the support from Jiangsu High-level Innovation and Entrepreneurship Talent Plan in 2017, National Key R\&D Program of China (2017YFB0102900), and Research Grant Council (26206115 and 16304117) of the Hong Kong Special Administrative Region, and Guangdong Spe- cial Fund for Science and Technology Development (Hong Kong Technology Cooperation Funding Scheme (201604030012, 201704030065). The electron microscopy work was carried out at the Center for Functional Nanomaterials, Brookhaven National Laboratory, which is supported by the U.S. Department of Energy (DOE), Office of Basic Energy Sciences, under Contract No. DE-SC-00112704. Use of the National Synchrotron Light Source at Brookhaven National Laboratory was supported by the U.S. Department of Energy, Office of Science, Office of Basic Energy Sciences, under Contract No. DE-AC02-98CH10886. Beamline X18A at the NSLS is supported in part by the Synchrotron Catalysis Consortium (DOE BES grant DE-FG02-03ER15688). The authors would like to acknowledge the support of Marianne Pemberton and Jonathan Odell with the synthesis and evaluation of catalysts, and Steven Ehrlich and Qi Wang for their assistance with the in situ XRD experiments performed at the NSLS.

\section{References}

[1] R. R. Adzic, J. Zhang, K. Sasaki, M. B. Vukmirovic, M. Shao, J. X. Wang, A. U. Nilekar, M. Mavrikakis, J. A. Valerio, F. Uribe, Top. Catal., 2007, 46, 249-262.

[2] M. Shao, Q. Chang, J.-P. Dodelet, R. Chenitz, Chem. Rev., 2016, 116, 3594-3657.

[3] M. Shao, G. He, A. Peles, J. H. Odell, J. Zeng, D. Su, J. Tao, T. Yu, Y.

\section{Graphical Abstract}

Chin. J. Catal., 2020, 41: 807-812 doi: S1872-2067(19)63451-0

\section{Interatomic diffusion in Pd-Pt core-shell nanoparticles}

Yanfeng Zhang, Shangqian Zhu, Lili Zhang, Dong Su, Minhua Shao* Jiangsu Aoxin NEV Co., Ltd, China;

Hong Kong University of Science and Technology, China;

Shanghai AI NEV Innovative Platform Co., Ltd, China;

Huaiyin Normal University, China;

Brookhaven National Laboratory, USA

The Pd@Pt core-shell structure can be destroyed by thermal annealing and lowers the activity toward oxygen reduction reaction.

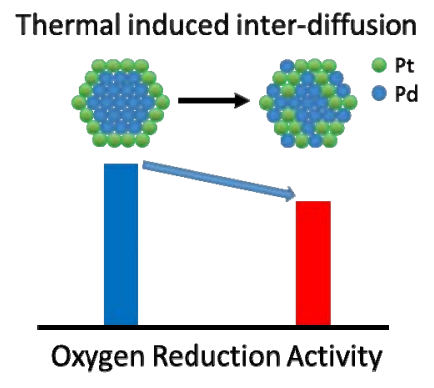


Zhu, Y. Xia, Chem. Commun., 2013, 49, 9030-9032.

[4] M. Shao, T. Huang, P. Liu, J. Zhang, K. Sasaki, M. B. Vukmirovic, R. R. Adzic, Langmuir, 2006, 22, 10409-10415.

[5] X. Wang, M. Vara, M. Luo, H. Huang, A. Ruditskiy, J. Park, S. Bao, J. Liu, J. Howe, M. Chi, Z. Xie, Y. Xia, J. Am. Chem. Soc., 2015, 137, 15036-15042.

[6] J. Zhang, F. H. B. Lima, M. H. Shao, K. Sasaki, J. X. Wang, J. Hanson, R. R. Adzic, J. Phys. Chem. B, 2005, 109, 22701-22704.

[7] J. Zhang, Y. Mo, M. B. Vukmirovic, R. Klie, K. Sasaki, R. R. Adzic, J. Phys. Chem. B, 2004, 108, 10955-10964.

[8] L. Zhang, S. Zhu, Q. Chang, D. Su, J. Yue, Z. Du, M. Shao, ACS Catal., 2016, 6, 3428-3432.

[9] M. Zhou, H. Wang, M. Vara, Z. D. Hood, M. Luo, T.-H. Yang, S. Bao, M. Chi, P. Xiao, Y. Zhang, Y. Xia, J. Am. Chem. Soc., 2016, 138, 12263-12270.

[10] J. Zhang, M. B. Vukmirovic, Y. Xu, M. Mavrikakis, R. R. Adzic, Angew. Chem. Int. Ed., 2005, 44, 2132-2135.

[11] V. Stamenkovic, B. S. Mun, K. J. J. Mayrhofer, P. N. Ross, N. M. Markovic, J. Rossmeisl, J. Greeley, J. K. Nørskov, Angew. Chem. Int. Ed., 2006, 45, 2897-2901.
[12] S. Khateeb, S. Guerreo, D. Su, R. M. Darling, L. V. Protsailo, M. Shao, J. Electrochem. Soc., 2016, 163, F708-F713.

[13] M. H. Shao, J. Power Sources, 2011, 196, 2433-2444.

[14] M. P. Humbert, B. H. Smith, Q. Wang, S. N. Ehrlich, M. Shao, Electrocatalysis, 2012, 3, 298-303.

[15] M. Shao, J. H. Odell, S.-I. Choi, Y. Xia, Electrochem. Commun., 2013, 31, 46-48.

[16] G. Alefeld, J. Völkl, in: Hydrogen in Metals I-Basic Properties, Berlin and New York, Springer-Verlag (Topics in Applied Physics. Volume 28), 1978. 442 p.(For individual items see A79-16057 to A79-16061), 1978.

[17] A. Rose, S. Maniguet, R. J. Mathew, C. Slater, J. Yao, A. E. Russell, Phys. Chem. Chem. Phys., 2003, 5, 3220-3225.

[18] J. K. Nørskov, J. Rossmeisl, A. Logadottir, L. Lindqvist, J. R. Kitchin, T. Bligaard, H. Jonsson, J. Phys. Chem. B, 2004, 108, 17886-17892.

[19] M. Shao, P. Liu, J. Zhang, R. Adzic, J. Phys. Chem. B, 2007, 111, 6772-6775.

[20] S. J. Yoo, H. Y. Park, T. Y. Jeon, I. S. Park, Y. H. Cho, Y. E. Sung, Angew. Chem. Int. Ed., 2008, 47, 9307-9310.

\section{钯铂核壳纳米催化剂颗粒中的原子扩散}

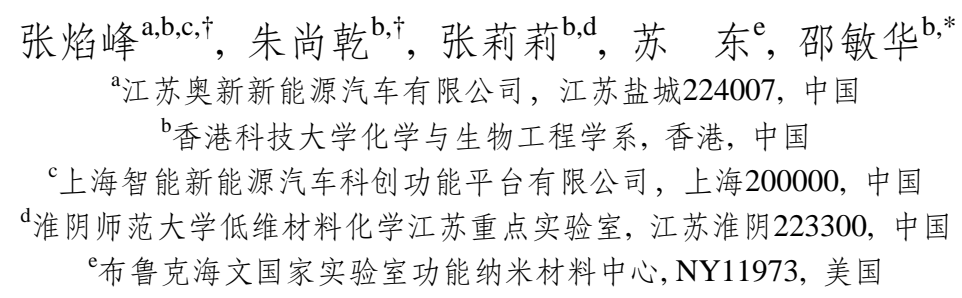

摘要: 铂原子单层的核壳结构催化剂因其高效的铂原子利用率和优异铂质量活性而广泛应用于燃料电池领域. 在该系列 材料中, 钯@铂核壳催化剂具有更优于纯铂的氧还原(ORR)催化活性, 因而拥有较好的应用前景. 但由于钯原子在热力学 上更倾向于富集到材料表面, 钯@铂核壳催化剂的催化稳定性及原子扩散的途径需要更深入的研究. 本文探究了热处理条 件对钯@铂核壳结构稳定性的破坏, 并确定了原子扩散对催化活性的影响.

原位扫描透射电子显微镜-电子能量损失谱(STEM-EELS)证明了在 $250{ }^{\circ} \mathrm{C}$ 的氩气氛围中, 钯@铂纳米颗粒中原本清晰 可见的1-2原子铂壳层已经消失, 并伴随着颗粒表面钯铂合金化的形成. 因钯金属可以吸收氢气而导致晶格间距的展宽, 钯@铂核壳结构的破坏也可以通过氢气氛围中的原位X射线衍射谱中(111)衍射峰的展宽和位移进行判断. 对钯@铂核壳 纳米催化剂进行一系列温度的热处理结果显示, 核壳结构的破坏在 $200{ }^{\circ} \mathrm{C}$ 左右开始, 并于 $200-300{ }^{\circ} \mathrm{C}$ 之间急剧发生. 一氧化 碳电化学氧化脱附实验表明, 热处理之后的核壳催化剂表面的一氧化碳氧化峰位置发生了明显的正移, 也证明了热处理之 后催化剂表面电子结构的变化. 核壳结构改变对催化活性的影响也通过旋转圆盘电极进行了测量. 相比于未经处理的样 品, $200{ }^{\circ} \mathrm{C}$ 处理之后的钯@铂核壳催化剂在 $0.9 \mathrm{~V}$ 电位处的质量活性损失了约 $37 \%$. 进一步提高热处理温度至 $300{ }^{\circ} \mathrm{C}$ 后, 钯 @铂核壳催化剂的质量活性只有初始状态的 $44 \%$. 本文揭示核壳结构中因热处理而导致的原子扩散现象, 并为燃料电池中 核壳催化剂的应用及膜电极的制备工艺条件提供了参考。

关键词: 核壳催化(单层)剂; 质子交换膜燃料电池; 稳定性; 原子扩散; 电催化剂

收稿日期: 2019-08-22. 接受日期: 2019-10-11. 出版日期: 2020-05-05.

*通讯联系人. 电话: (+852)34692269; 电子信箱: kemshao@ust.hk

†共同第一作者.

基金来源：国家重点研发计划(2017YFB0102900); 香港特别行政区研究资助局(26206115，16304117); 广东省科技发展专项基金 (香港科技合作资助计划(201604030012, 201704030065)).

本文的电子版全文由Elsevier出版社在ScienceDirect上出版(http://www.sciencedirect.com/science/journal/18722067). 